\title{
PERAN PENDIDIKAN DALAM PENYULUHAN AGAMA DI MASYARAKAT
}

\author{
Munawiroh \\ Puslitbang Pendidikan Agama dan Keagamaan | Balitbang dan Diklat Kemenag RI \\ Jl. MH Thamrin No.06 Jakarta Pusat | Email: mun.asrori@gmail.com
}

\begin{abstract}
This paper draws on the results of research on the Role of Education in Religious Counseling in the Community, which describes how education plays its role in religious counseling activities. The study was conducted in seven provinces, i.e. East Java, West Java, Central Java, North Sumatra, Bali, Central Kalimantan and East Nusa Tenggara. The data were collected by using questionnaires. The findings show that religious counselors understand about the education role they must play in their counseling programs. The activities categorized as the role of education in counseling include religious sermons, regular recitation, group discussion, and individual consultations. The materials provided may vary according to the needs of the community. On the other hand, the obstacles during the performance of their education role include, among others, considered low benefits, inadequate means of transportation, short availability of textbooks, and lack of public enthusiasm in participating in the counseling.
\end{abstract}

Keywords: Role, Education, Religious Counselor

\section{Abstrak}

Tulisan ini diangkat dari hasil penelitian tentang Peran Pendidikan dalam Penyuluhan Agama di Masyarakat, yang memaparkan bagaimana peran pendidikan yang dijalankan dalam kegiatan penyuluhan agama. Penelitian tersebut dilakukan pada tujuh propinsi, mencakup Jawa Timur, Jawa Barat, Jawa Tengah, Sumatera Utara, Bali, Kalimantan Tengah dan Nusa Tenggara Timur. Penjaringan data menggunakan angket. Hasil temuannya menunjukan bahwa para penyuluh agama telah memahami peran pendidikan yang harus dijalankan dalam kegiatan penyuluhan yang dilakukan. Aktifitas yang dikategorikan sebagai peran pendidikan dalam penyuluhan seperti ceramah, pengajian rutin, diskusi kelompok, dan konsultasi perorangan. Materi pendidikan yang diajarkan bervariasi, sesuai dengan kebutuhan masyarakat. Sedangkan hambatan yang dihadapi penyuluh dalam menjalankan peran pendidikan, antara lain tunjangan yang dinilai masih rendah, alat transfortasi kurang memadai, kurang tersedianya buku bahan ajar, dan masih rendahnya perhatian masyarakat dalam mengikuti penyuluhan.

Kata Kunci: Peran, Pendidikan, Penyuluh Agama

\section{PENDAHULUAN}

Penyuluhan agama merupakan salah satu bentuk satuan kegiatan yang memiliki nilai strategis dalam pelaksanaan pembangunan di bidang keagamaan. Tugas tersebut dilakukan oleh Penyuluh Agama. Penyuluh Agama adalah PNS yang tugas pokoknya sebagimana diatur dalam SK Menko Wasbang dan PAN ${ }^{1}$ Nomor 54/

${ }^{1}$ Menurut SK tersebut, kualifikasi Penyuluh Agama terbagi kepada Penyuluh agama Kementerian dan Instansi. Penyuluh Agama Kementerian berkedudukan di kantor Kementerian Agma Pusat, Propinsi dan Kabupaten Kota, sedang Penyuluh Agama Instansi berkedudukan di Kantor Instansi atau LPND, Pemda tingkat Provinsi, Kabupaten/Kota, BUMN dan instansi lainnya. Pembidangan Penyuluh Agama, meliputi bidang 
Kep/MK.WASPAN/9/1999, yaitu melakukan dan mengembangkan kegiatan bimbingan atau penyuluhan agama dan pembangunan melalui bahasa agama. Mereka diberi tugas, tanggung jawab dan wewenang secara penuh untuk melakukan kegiatan bimbingan keagamaan dan penyuluhan pembangunan melalui bahasa agama.

Penyuluh Agama mempunyai peranan penting dalam kehidupan beragama, bermasyarakat dan bernegara, antara lain: sebagai pembimbing masyarakat, sebagai panutan dan sebagai penyambung tugas pemerintah. Tugas pokok penyuluh agama sebagaimana tercantum dalam KMA No 516 Tahun 2003 adalah melaksanakan bimbingan atau penyuluhan agama dan mengembangkan bimbingan atau penyuluhan agama dan pembangunan melalui bahasa agama. Dalam pelaksanaan bimbingan dan penyeluhan mempunyai tiga fungsi yang melekat dalam diri penyuluh, antara lain: pertama, fungsi informatif dan edukatif. Penyuluh Agama Islam memposisikan dirinya sebagai da'i yang berkewajiban menda'wahkan Islam, menyampaikan penerangan agama dan mendidik masyarakat dengan sebaik-baiknya sesuai ajaran agama. Kedua, fungsi konsultatif. Penyuluh Agama Islam menyediakan dirinya untuk turut memikirkan dan memecahkan persoalan-persoalan yang dihadapi masyarakat, baik secara pribadi, keluarga maupun sebagai anggota masyarakat umum. Ketiga, fungsi advokatif. Penyuluh Agama Islam memiliki tanggung jawab moral dan sosial untuk melakukan kegiatan advokasi (pembelaan) terhadap umat/masyarakat dari berbagai ancaman, gangguan, hambatan dan tantangan yang dapat menggoyahkan aqidah, mengganggu pelaksanaan ibadah dan merusak akhlak dan tatanan moral umat/masyarakat.

Kendati demikian, Penyuluh Agama dalam kegiatan penyuluhan agama masih dihadapkan pada sejumlah permasalahan, di antaranya:

penyuluhan Agama Islam, Kristen, Katholik, Hindu dan Buddhadan Penyuluh Agama Spesialis.
(1) Penyuluh agama belum memahamai secara komprehensif mengenai konsep dasar penyuluhan, pendekatan penyuluhan, teknikteknik penyuluan dan teori-teori penyuluhan. Bahkan Penyuluh Agama banyak yang belum membaca buku-buku pedoman penyuluhan yang yang diterbitkan Kemenag. (2) Penyuluh Agana masih lemah dalam memahami metodologi dalam proses penyuluhan. Salah satu indikasinya, dalamn pelaksanaan penyuluhan masih cenderung menggunakan metode konvensional seperti ceramah satu arah, dan (3) Penyuluh Agama masih sangat terbatas mengikuti Diklat Penyuluhan yang berakibat belum memadainya proses pelaksanaan penyuluhan, pendekatan dan kemampuan metodis para penyuluh. ${ }^{2}$

Ketimpangan antara tuntutan profesi dengan kenyataan (baca: kemampuan) para Penyuluh Agama berakibat pada belum dapat diimplementasikannya dalam tugas-tugas penyuluhan dan pembinaan yang di dalamnya mengandung dimensi pendidikan atas berbagai lapisan kelompok masyarakat. Kondisi ini dapat diketahui dari hasil penelitian Puslitbang Penda Tahun 2009, yang menyimpulkan bahwa pelayanan pendidikan di kelompok-kelompok anak jalanan, penghuni Lapas, tenmpat Prostitusi, pelabuhan kapal, rumah singgah, dan lain-lain belum terlayani secara maksimal baik pendidikan formal maupun pendidikan nonformal termasuk di dalamnya pendidikan agama dan keagamaan. ${ }^{3}$

Berdasarkan latar belakang tersebut, terdapat ketimpangan antara tuntutan tugas penyuluh agama dengan pelaksanaan kegiatan pendidikan yang mejadi tanggung jawab Penyuluh Agama dan bagaimana posisi pendidikan baik dalam pandangan penyuluh agama maupun kaitannya dengan regulasi penyuluhan agama tugas pokok para penyuluh agama. Permasalahan tersebut

${ }^{2}$ M. Daud. Laporan Penelitian Evaluasi Kinerja Penyuluh. Widyaiswara Utama Balai Diklat Keagamaan Palembang. 2011.

${ }^{3}$ Puslitbang Pendidikan Agama dan Keagamaan, 2009. Laporan Hasil Penelitian Pendidikan ALternatif. 
akan difokuskan untuk menjawab: pertama, bagaimana kedudukan (posisi) pendidikan dalam penyuluhan agama. Kedua, seperti apa pelaksanaan aktivitas pendidikan dalam penyuluhan agama, dan ketiga, apa hambatan dan peluang Penyuluh Agama dalam melaksanakan aktivitas pendidikan dalam penyuluhan agama.

Hasil penelitian ini bisa dijadikan bahan studi awal tentang hubungan penyuluh agama dan pendidikan, terutama pendidikan non formal yang diselenggarakan masyarakat. Secara praktis, dapat dijadikan bahan rujukan dan pertimbangan dalam merumuskan kebijakan unit teknis dalam hal ini Direktorat Jenderal Bimas Islam, Kristen, Katolik, Hindu dan Budha, Direktorat Pendidikasn Diniyah dan Pondok Pesantren Ditjend Pendis, Kementerian Agama RI.

\section{Kerangka Konseptual}

\section{Konsep Penyuluhan}

Istilah penyuluhan secara umum adalah ilmu sosial yang mempelajari sistem dan proses perubahan pada individu serta masyarakat agar dapat terwujud perubahan yang lebih baik sesuai dengan yang diharapkan. ${ }^{4}$ Penyuluhan merupakan keterlibatan seseorang untuk melakukan komunikasi informasi secara sadar dengan tujuan membantu sesamanya memberikan pendapat sehingga bisa membuat keputusan yang benar. ${ }^{5}$

Manfaat Penyuluhan, diharapkan terjadi peningkatan pengetahuan, keterampilan dan sikap. Pengetahuan dikatakan meningkat bila terjadi perubahan dari tidak tahu menjadi tahu dan yang sudah tahu menjadi lebih tahu. Keterampilan dikatakan meningkat bila terjadi perubahan dari yang tidak mampu menjadi mampu melakukan suatu pekerjaan yang

${ }^{4}$ L. Setiana. 2005. Evaluasi Penyuluhan. Jakarta: Universitas Terbuka,h. 59

${ }^{5}$ A.W. van den Ban dkk. 1999. Penyuluhan Pertanian. Yogyakarta: Kanisius, h. 72 bermanfaat. Sikap dikatakan meningkat, bila terjadi perubahan dari yang tidak mau menjadi mau memanfaatkan kesempatan-kesempatan yang diciptakan.

Daribeberpapengertiandiatas, penyuluhan berarti: pertama, sebagai proses perubahan perilaku masyarakat agar mereka tahu, mau dan mampu melakukan perubahan. Untuk keberhasilannya penyuluhan tidak berhenti pada "penyebarluasan informasi/inovasi", dan "memberikan penerangan", harus dilakukan secara terus-menerus, sampai terjadinya perubahan perilaku yang ditunjukkan oleh penerima manfaat penyuluhan (beneficiaries) yang menjadi "klien" penyuluhan". Kedua, sebagai proses belajar yang berupa kegiatan penyebarluasan informasi dan penjelasan yang diberikan dapat merangsang terjadinya proses perubahan perilaku yang dilakukan melalui proses pendidikan atau kegiatan belajar, yang dapat dilakukan melalui beragam cara, seperti: pembujukan, pemberian insentif/hadiah, atau bahkan melalui kegiatan-kegiatan pemaksaan (baik melalui penciptaan kondisi lingkungan fisik maupun social-ekonomi, maupun pemaksaan melalui aturan dan ancamanancaman).

Ketiga, sebagai proses perubahan social untukmemperbaiki kehidupan masyarakatnya, tidak saja perubahan (perilaku) baik pada diri seseorang, tetapi juga perubahanperubahan hubungan antar individu dalam masyarakat, termasuk struktur, nilai-nilai, dan pranata sosialnya, seperti: demokratisasi, transparansi, supremasi hukum, dan lain-lain. Keempat, sebagai proses rekayasa sosial (social engineering) untuk menyiapkan sumberdaya manusia agar mereka tahu, mau dan mampu melaksanakan perannya sesuai dengan tugas pokok dan fungsinya dalam sistem sosialnya masing-masing. Kelima, sebagai proses pemasaran sosial (Social Marketing), yaitu penerapan konsep dan atau teori-teori pemasaran dalam proses perubahan sosial. untuk "menawarkan" (to do for) sesuatu kepada 
masyarakat. yang pengambilan keputusannya berada di tangan masyarakat itu sendiri.

Keenam, sebagai proses pemberdayaan masyarakat (community empowerment), yaitu bahwa kegiatan penyuluhan dimaksudkan untuk memberdayakan masyarakat agar lebih bermanfaat bagi masyarakat yang bersangkutan, sehingga tercipta masyarakat madani. Ketujuh, sebagai proses penguatan kapasitas (capacity strenghtening), yaitu penguatan kemampuan setiap individu, kelembagaan, hubungan antar individu, kelompok organisasi sosial, serta pihak lain di luar sistem masyarakatnya, sampai di aras global. untuk memobilisasi dan memanfaatkan sumberdaya yang dimiliki secara lebih berhasilguna, berdayaguna secara berkelanjutan. Ketujuh, sebagai proses komunikasi pembangunan untuk menumbuhkembangkan partisipasi masyarakat dalam pembangunan.

\section{Pendidikan dan Pendidikan Masyarakat}

Pengertian pendidikan dikemukakan oleh beberapa ahli sebagai berikut: (1) Pendidikan adalah "usaha sadar yang dengan sengaja dirancangkan untuk mencapai tujuan yang telah ditetapkan. ${ }^{6}$ (2) Pendidikan merupakan usaha manusia untuk menumbuhkan dan mengembangkan potensi-potensi pembawaan, baik jasmani maupun rohani sesuai dengan nilai-nilai yang ada di dalam masyarakat dan kebudayaan. (Ihsan; 1996: 1). ${ }^{7}$

Selanjutnya, berkenaan dengan jalur pendidikan dapatberupa formal dan nonformal. Pendidikan nonformal berbasis masyarakat diselenggarakan oleh masyarakat sebagai pengganti, penambah dan/pelengkap pendidikan formal yang berfungsi mengembangkan potensi peserta didik dengan penekanan pengetahuan dan keterampilan

${ }^{6}$ Piet A. Sahertian. 2000. Konsep-Konsep dan Teknik Supervisi Pendidikan Dalam Rangka Pengembangan Sumber Daya Manusia, Jakarta: Rineka Cipta.

${ }^{7}$ Hamdani Ihsan dan Fuad Ahmad, 2007. Filsafat Pendidikan Islam, CV Pustaka Setia, Bandung. fungsional serta pengembangan sikap dan kepribadian.

Pendidikan masyarakat (communityeducation) memberikan peluang bagi setiap orang untuk memperkaya ilmu pengetahuan dan teknologi melalui pembelajaran seumur hidup. Karena itu, pendidikan harus dikelola secara desentralisasi dengan cara mengajak masyarakat untuk berpartisipasi sebagai upaya kolaboratif, antara warga dengan pemerintah dalam merencanakan, melaksanakan, menjaga dan mengembangkan aktivitas pendidikaan yang dapat menampung dan mengakomodir pertispirasi tersebut dalam perencanaan dan pelaksanaan program pendidikan. Secara konseptual, pendidikan masyarakat adalah model penyelenggaraan pendidikan yang bertumpu pada prinsip "dari masyarakat, oleh masyarakat dan untuk masyarakat".

\section{Penyuluh Agama}

Penyuluh Agama adalah Pegawai Negeri Sipil yang diberi tugas, tanggung jawab dan wewenang secara penuh oleh pejabat yang berwenang untuk melakukan kegiatan bimbingan keagamaan dan penyuluhan pembangunan melalui bahasa agama. Sedang sasaran penyuluhan meliputi: kelompok sasaran masyarakat umum (pedesaan dan transmigrasi); kelompok sasaran masyarakat perkotaan, masyarakat sekitar kawasan industri, kelompok sasaran masyarakat khusus, generasi muda, Lembaga Pendidikan Masyarakat, msyarakat binaan khusus, daerah terpencil dan suku terasing (masyarakat daerah terpencil dan masyarakat suku terasing).

\section{Konsep Peranan}

Menurut W.J.S. Poerwadaminta ${ }^{8}$ peranan berarti sesuatu yang menjadi bagian atau memegang pimpinan yang terutama. Bagi Levinson peranan adalah suatu konsep

${ }^{8}$ WJS Poerwadarminta. 1985. Kamus Umum Bahasa Indonesia. Jakarta: Balai ustaka. h. 735 
prihal apa yang dapat dilakukan individu dan penting bagi struktur sosial masyarakat. Soejono Soekanto menyatakan bahwa peranan meliputi norma-norma yang dikembangkan dengan posisi atau tempat seseorang dalam masyarakat, di dalamnya ada serangkaian peraturan yang membimbing seseorang dalam kehidupan masyarakat. ${ }^{9}$ Menurut Biddle dan Thomas, peran adalah serangkaian rumusan yang membatasi prilaku-prilaku yang diharapkan dari pemegang kedudukan tertentu.

Peranan menurut Getzels (1967) bersifat kebenaran normatif dan menetapkan batasanbatasan kewajiban-kewajiban apa yang harus dilakukan dan apa yang tidak boleh dilakukan seseorang secara khusus di dalam suatu organisasi. Lipham \& Hoeh (1974) menyatakan bahwa peranan adalah aspek dinamis yang melekat pada posisi atau status seseorang di dalam suatu organisasi. Karena itu peran berkembang terus sesuai dengan tuntutan kebutuhan organisasi. ${ }^{10}$

Dari beberapa definisi itu peranan bisa disimpulkan adalah tingkah laku yang diharapkan dari orang yang memiliki kedudukan atau status yang tidak bisa dipisahkan di antara keduanya. Peranan tersebut meliputi norma-norma yang berhubungan dengan posisi seseorang dalam masyarakat, konsep tentang apa yang dapat dilakukan individu di masyarakat, dan sebagai perilaku individu yang penting bagi struktur sosial masyarakat. Peranan harus berkaitan dengan fungsi atau sebaliknya fungsi berkaitan dengan peranan.

\section{Peran Pendidikan dalam Penyuluhan Agama di Masyarakat}

Peranan pendidikan dalam penyuluhan agama di masyarakat memiliki dimensi keberadaan posisi pendidikan dalam penyuluhan

${ }^{9}$ Soejono Soekanto. 1982. Manajemen Sumber Daya Manusia. Jakarta: Gramedia Pustaka Utama. h. 238

${ }^{10}$ Getzels. (1967. Sosiologi Pendidikan. DP Press. h.58 agama, terkait dengan, pertama pengetahuan penyuluh agama terhadap pendidikan maupun penyuluhan, serta tugas pokok penyuluh agama, serta posisi pendidikan dalam regulasi penyuluhan agama. Dimaksud dengan regulasi penyuluhan agama termaktub dalam KMA N0. 516 Tahun 2003 tentang juknis penyuluh agama. Dalam KMA ini memuat: kedudukan, tugas pokok, jenis, kegiatan, pembinaan penyuluh agama. Kedua, pelaksanaan aktivitasaktivitas pendidikan, meliputi keberadaan aktivitas pendidikan, dan pelaksanaan aktivitas pendidikan dalam penyuluhan agama.

\section{METODOLOGI}

Metode Penelitian ini menggunakan metode kuantitatif dengan teknik survei. Survei ini diharapkan dapat memotret posisi pendidikan menurut penyuluh agama dan aktivitas pendidikan yang dilakukan penyuluh agama dalam kegiatan penyuluhan agama. Selain survei, penelitian ini juga menggunakan metode kualitatif.

Populasi sampling adalah seluruh penyuluh agama yang berstatus Pegawai Negeri Sipil di Indonesia Tahun 2011 yang berjumlah 6163 orang. Target populasi yang menjadi sasaran penelitian adalah seluruh penyuluh agama yang berstatus PNS di 7 propinsi, yaitu: Jawa Timur, Jawa Barat, Jawa Tengah, Sumut, Bali, Kalteng, dan NTT. Pemilihan ketujuh propinsi berdasarkan pertimbangan quota bidang penyuluh agama. Seluruh penyuluh agama yang bersatatus PNS di 7 propinsi berjumlah 2.995 orang. Penentuan jumlah sampel penyuluh agama menggunakan rumus Slovin dengan Margin of Eror (MoE) $4 \%$ dan tingkat kepercayaan $95 \%$ sebesar 520 penyuluh agama. Dengan mempertimbangkan tingkat non-respons sebesar 5\%, kecuali untuk Islam, jumlah sampel ditingkatkan menjadi 572 penyuluh agama.

Jumlah sampel dialokasikan ditiap propinsi menurut proporsi persebaran populasi. Sampel di tiap propinsi adalah: Jatim (135), Jabar (110), 
Jateng (127), Sumut (83), Bali (41), Kalteng (48) dan NTT (28). Selanjutnya, di tiap propinsi sampel dialokasikan untuk masing-masing bidang penyuluh agama (Islam, Kristen, Katholik, Hindu, Budha) menurut proporsi persebaran polpulasi. Prosedur pengambilan responden penyuluh agama di masing-masing propinsi dilakukan oleh tenaga pengumpul data (TPD) di lapangan secara purposive.

Instrumen penelitian adalah kuesioner. Untuk menguji akurasi dan presisi hasil survei ini, dilakukan cross-check data sampel dengan data populasi penyuluh agama bestatus PNS pada Dirjen Bimas Islam tahun 2011. Validasi sampel dimaksudkan untuk mendapatkan kesesuaian, ketepatan, atau kedekatan data sampel terhadap populasi yang diteliti. Sementara pengujian validasi instrumen dimaksudkan untuk mendapatkan akurasi subtansi item pertanyaan berdasarkan konstruk konsep yang digunakan.

Karena alasan teknis dan prosedural, pengisian kuesioner dilakukan oleh responden sendiri dengan cara dikumpulkan dalam satu tempat dengan disaksikan langsung oleh peneliti dan petugas daerah. Namun demikian alasan-alasan metodologis terabaikan. Karena pengisian kuesioner idealnya mengggunakan teknik enumerasi, yaitu interview tatap muka untuk proses pengisian kuesioner. ${ }^{11}$

Setelah data terkumpul, data divalidasi dan dikoding. Selanjutnya data diolah melalui tahapan berikut: persiapan entry data, entry data, tabulasi data, dan editing data. Kemudian data dianalis melalui metode statistik deskriptif.

11 jika teknik ini dipilih untuk beberapa alasan metodologis: pertama, menghindari kemungkinan kuesioner diisi oleh responden yang salah-tidak tepat, kedua, membantu responden untuk memahami pertanyaan-pernyataan dalam kuesioner, dan ketiga, menjaga kelengkapan data yang dibutuhkan. Face-to-face interview, secara normatif, sangat dapat memfasilitasi peneliti untuk melengkapi data yang dibutuhkan.

\section{HASIL DAN PEMBAHASAN}

\section{Profil Responden}

Instrumen yang disebarkan sebanyak 572 responden, data yang masuk sebanyak 557 responden, berarti ada 15 responden yang tidak terealisasi dengan alasannya data penyuluh yang diperoleh dengan kenyataan di lapangan berbeda disebabkan dari beberapa lokasi banyak penyuluh beralih fungsi menjadi staf dan dosen, juga di wilayah Jawa barat ternyata jumlah penyuluh bertambah, oleh karena itu hasil dari penelitian ini terjadi perubahan/ pergeseran sampel.

Berdasarkan wilayah responden, didapat sebagai berikut: 154 atau $(27,65 \%)$ penyuluh agama Jawa Barat, 127 atau $(22,8 \%)$ penyuluh agama Jawa Tengah, 99 atau $(17,77)$ penyuluh agama Jawa Timur, 60 atau $(10,77 \%)$ penyuluh agama Sumut, 48 atau ( $8,62 \%)$ penyuluh agama Kalimantan Tengah, 41 atau (7,36\%) penyuluh agama Bali dan 28 atau $(5,03)$ penyuluh agama Nusa Tenggara Timur.

Dilihat dari jenis kelamin dan usia responden, 223 atau (40.04\%) penyuluh agama perempuan dan 334 atau (59.96\%) penyuluh agama laki-laki. Sedangkan usia mereka, 9 atau $(1,62 \%)$ berusia dibawah 30 tahun; 295 atau $(52,97 \%)$ berusia antara $31 \mathrm{~s} / \mathrm{d} 40$ tahun; 246 atau $(44,16 \%)$ berusia 40 tahun keatas; dan 7 atau $(1,25 \%)$ tidak menyebutkan usia mereka. Data ini menunjukkan bahwa kebanyakan usia penyuluh diatas 31 tahun, menurut teori ilmu psikologi perkembangan bahwa usia 15-59 tahun adalah usia produktif, yaitu usia yang mampu bekerja dan diharapkan bisa menghasilkan sesuatu. Demikian juga dengan penyuluh seyogyanya mereka bisa memberikan pelayanan sesuai dengan tugas yang dipikulnya sehingga masyarakat semakin bisa dewasa dan cerdas mampu menerima tantangan zaman kedepan.

Dilihat dari jurusan dan jenjang pendidikan, 1 orang berpendidikan SMP, 16 orang berpendidikan SMA, 13 orang berpendidikan D1/Sarjana Muda, 424 orang 
berpendidikan S1, 60 orang berpendidikan S2, 2 orang berpendidikan S3, dan 2 orang tidak menyebutkan pendidikan terakhirnya. Sedangkan dari segi jurusan, para penyuluh bervariasi, yaitu 498 orang jurusan agama, 15 orang jurusan pendidikan, 7 orang jurusan ekonomi, 4 orang jurusan hukum, 1 orang jurusan tehnik, dan jurusan lainnya (Psikologi, komunikasi, manajemen, administrasi) sebanyak 6 orang. Selain itu terdapat 26 orang yang tidak menyebutkan jurusan pendidikannya.

Adanya 1 orangyangberjenjang pendidikan SMP dan 33 orang bukan berlatarbelakang agama dapat menjadi keprihatinan Kementerian Agama. Jika seorang penyuluh agama tidak berbasis agama atau pendidikan, mampukah mereka memberikan bimpingan dan penyuluhan kepada masyarakat. Padahal didalam KMA N0.516 Tahun 2003 disebutkan bahwa latar belakang pendidikan penyuluh agama minimal sarjana muda dan jurusan agama.

Jumlah penyuluh agama dengan latar belakang pendidikan agama lebih banyak mendapat diklat, 1,2,3,4,5,6 terutama pada diklat 4, dibandingkan penyuluh dengan latar belakang pendidikan Nonagama, padahal kelompok kedua ini lebih memerlukan dikat. Secara rinci dapat dilihat pada tabel 2 dibawah ini:

Tabel 1.

Jumlah Keikutsertaan Diklat

\begin{tabular}{|l|c|c|c|c|c|c|c|c|c|c|}
\hline \multirow{2}{*}{$\begin{array}{l}\text { Latar } \\
\text { Belakang } \\
\text { Pend. }\end{array}$} & \multicolumn{7}{|c|}{ Jumlah Keikutsertaan Diklat } & \multirow{2}{*}{} \\
\cline { 2 - 11 } & 0 & 1 & 2 & 3 & 4 & 5 & 6 & 7 & 8 & Total \\
\hline Agama & 32 & 133 & 148 & 106 & 53 & 10 & 16 & 0 & 0 & 498 \\
\hline Nonagama & 14 & 15 & 14 & 11 & 1 & 1 & 1 & 1 & 1 & 59 \\
\hline \multicolumn{10}{|c|}{} & \\
\hline
\end{tabular}

Dari tabel diatas diketahui bahwa penyuluh yang belum pernah mengikuti diklat sebanyak 46 orang dan sebagian besar $\pm 30 \%$ mereka baru ikut diklat sebanyak 2 kali. Padahal seorang penyuluh bisa diangkat menjadi penyuluh apabila sudah mengikuti diklat calon penyuluh. Diklat yang ada mempunyai 3 tahap, yaitu diklat calon penyuluh, diklat tingkat lanjutan dan diklat tingkat mahir. ${ }^{12}$

Dilihat dari jabatan penyuluh dan bidang penyuluhan adalah sebagai berikut. Penyuluh agama Islam sebanyak 399 orang yang terdiri dari: penyuluh tingkat lanjutan 21 orang, penyelia 18 orang, pertama 177 orang, muda 149 orang, madya 32 orang dan utama 2 orang. Penyuluh agama Kristen sebanyak 32 orang yang terdiri dari penyuluh tingkat lanjutan 1 orang, pertama 12 orang, muda 14 orang, madya 4 orang dan utama 1 orang. Penyuluh agama katholik sebanyak 30 orang yang terdiri dari penyuluh tingkat penyelia 1 orang, pertama 12 orang, muda 15 orang, madya 2 orang dan utama 1 orang. Penyuluh agama Hindu sebanyak 39 orang yang terdiri dari penyuluh tingkat pelaksana 1 orang, lanjutan 2 orang, penyelia 6 orang, pertama 10 orang, muda 10 orang, dan madya 10 orang. Penyuluh agama Budha sebanyak 13 orang, terdiri dari penyuluh tingkat pertama 6 orang dan tingkat muda 7 orang.

Kelompok sasaran penyuluhan agama masih banyak didominasi pada salah satu sasaran tertentu, misalnya, 364 penyuluh agama Islam hanya terfokus pada majelis taklim, 245 penyuluh agama Islam terfokus pada TPA/TPQ, dan 181 penyuluh agama Islam terfokus kepada remaja masjid. Berikut tabel 3 kelompok sasaran penyuluh agama:

Tabel 2.

Kelompok Sasaran

\begin{tabular}{|l|l|l|l|l|l|}
\hline No. & Kelompok Sasaran & Jumlah & No. & Kelompok Sasaran & Jumlah \\
\hline 1. & Majelis Taklim & 364 & 11. & Anak Jalanan & 60 \\
\hline 2. & Pondok Pesantren & 72 & 12. & Lokalisasi PSK & 35 \\
\hline 3. & TPA/TPQ & 245 & 13. & $\begin{array}{l}\text { Lembaga } \\
\text { Pemasyarakatan }\end{array}$ & 118 \\
\hline 4. & Remaja Masjid & 181 & 14. & Pasraman & 18 \\
\hline 5. & $\begin{array}{l}\text { Wanita Hindu } \\
\text { Dharma }\end{array}$ & 14 & 15. & Sekolah Minggu & 24 \\
\hline
\end{tabular}

${ }^{12}$ Diklat yang dilaksanakan oleh Pusdiklat Tenaga Teknis Keagamaan 


\begin{tabular}{|l|l|l|l|l|l|}
\hline 6. & $\begin{array}{l}\text { Persatuan Wanita } \\
\text { gereja }\end{array}$ & 26 & 16. & Karang Taruna & 218 \\
\hline 7. & Pesantian & 23 & 17. & Pramuka & 29 \\
\hline 8. & $\begin{array}{l}\text { Persatuan Wanita } \\
\text { Budha }\end{array}$ & 14 & 18. & $\begin{array}{l}\text { Masyarakat } \\
\text { terpencil }\end{array}$ & 3 \\
\hline 9. & Panti Rehabilitasi & 52 & 19. & Suku Terasing & 1 \\
\hline 10. & Rumah Sakit & 31 & & & \\
\hline
\end{tabular}

Melihat tabel diatas penyuluh agama dalam pelaksanaan tugasnya terfokus pada salah satu sasaran (contohnya untuk Islam majelis taklim) padahal didalam petunjuk teknis implementasi dari KMA No.516 Tahun 2003, setiap penyuluh wajib melakukan tugas kepenyuluhannya pada satu desa binaan dan 3 kelompok sasaran.

\section{Peran Pendidikan dalam Penyuluhan Agama di Masyarakat}

Peran pendidikan dalam kegiatan penyuluhan agama di masyarakat akan dijelaskan melalui tiga pembahasanm yaitu: kedudukan (posisi) pendidikan dalam penyuluhan agama, pelaksanaan aktivitas pendidikan dalam penyuluhan agama, dan hambatan dan peluang Penyuluh Agama dalam melaksanakan aktivitas pendidikan dalam penyuluhan agama.

\section{Posisi Pendidikan dalam Penyuluhan Agama}

Secara umum penyuluh agama telah memahami tentang penyuluhan dan pendidikan, hal ini diperlihatkan bahwa 99,08\% penyuluh agama paham tentang penyuluhan, dan $99,06 \%$ penyuluh agama paham tentang pendidikan. Data ini sejalan dengan pendapat penyuluh agama (97\%) yang menyatakan bahwa penyuluhan adalah termasuk pendidikan. Meskipun aktifitas terbesar penyuluh agama adalah menyampaikan pesan Agama sebesar $63,09 \%$, tetapi sebesar $32,05 \%$ penyuluh agama yang aktivitasnya juga membina atau mendidik masyarakat. Jika penyampaian pesan agama dikategorikan sebagai unsur pendidikan maka kegiatan penyuluh agama terkait dengan posisi pendidikan sebesar 96,4\%. Dalam aktifitas diatas apakah penyuluh agama memerlukan standar untuk mendukung pelaksanaan kegiatan, 521 penyuluh agama menjawab ya dan 4 penyuluh agama menjawab tidak.

Bagaimana pandangan penyuluh agama terkait adanya posisi pendidikan dalam Regulasi (KMANo.516Th2003).Dariperspektif penyuluh agama, posisi pendidikan dalam KMA No.516 Tahun 2003 dianggap masih belum memadai. Hal ini didasarkan atas lebih banyak penyuluh agama yang berpendapat "belum memadai" dibanding "memadai", perbandingannya (48\%) dan (44\%). Terkait dengan Aspek-aspek yang kurang memadai dalam KMA No.516 Tahun 003 adalah: pengertian penyuluh, tugas pokok penyuluh, kegiatan penyuluh, pembinaan, penilaian penyuluh, dan jenjang jabatan.

Terkait dengan jenjang karier apakah sudah diataur/memadai dalam regulasi (KMA No. 516). Dari 246 penyuluh agama menyatakan sudah diatur dan memadai dalam regulasi, dan 267 penyuluh menjawab belum memadai, serta 44 penyuluh agama tidak menjawab/ tidak valid. Ketika penyuluh agama ditanya pembinaan terkait dengan jenjang karir yang mereka harapkan adalah pengembangan jenjang karir. Jenjang karir yang diharapkan, di antaranya adalah: kenaikan pangkat/ pindah kejabatan yang lebih tinggi, kenaikan tunjangan, perhatian pemerintah, dan bea siswa.

Sebagian besar penyuluh agama berpendapat bahwa dalam Regulasi KMA No.516 Tahun 2003 terdapat unsur tugas pendidikan. Hal ini sesuai $70 \%$ penyuluh agama yang menjawab bahwa ada unsur pendidikan dalam KMA. Dari hasil wawancara peneliti di lapangan diperoleh bahwa mereka yang menjawab tidak tahu sebesar $20 \%$ ternyata mereka belum tahu tentang keberadaan KMA tersebut. Ini membuktikan bahwa sosialisasi KMA belum seluruhnya menjamah para penyuluh. 


\section{Aktifitas Pendidikan dalam Penyuluhan Agama}

Aktifitas pendidikan dalam tugas penyuluh agama antara lain: ceramah, pengajian atau ibadah rutin, diskusi kelompok, konsultasi perorangan, dan menjadi narasumber. Hal ini didasarkan atas pendapat penyuluh sebagai berikut:

Tabel 3.

Aktifitas Penyuluh

\begin{tabular}{|l|l|l|}
\hline No & Kegiatan Pedidikan & $\begin{array}{l}\text { Jumlah Responden yang } \\
\text { berpendapat }\end{array}$ \\
\hline 1 & Ceramah & 534 \\
\hline 2 & Pengajian/lbadah Rutin & 439 \\
\hline 3 & Diskusi Kelompok & 254 \\
\hline 4 & Konsultasi Perorangan & 114 \\
\hline 5 & Narasumber kegiatan & 42 \\
\hline
\end{tabular}

Durasi aktivitas penyuluh agama yang termasuk dalam kegiatan pendidikan sebagian besar antara 4 sampai 8 jam perminggu 221 atau $50,39 \%$ penyuluh agama, dibawah 4 jam perminggu sebesar 106 atau $19 \%$ penyuluh agama dan diatas 8 jam permingu sebanyak 187 atau 35,4\% penyuluh agama.

Materi yang diajarkan penyuluh agama sangat bervariasi. Dari beberapa jawaban responden dapat digambarkan sebagai berikut: untuk materi bidang penyuluhan agama Islam adalah 30\% aqidah, 25\% Akhlak, 20\% Fiqih, 15\% Al-Qur'an, 10\% SKI; untuk materi bidang penyuluhan agama Kristen adalah 35\% keimanan, 25\% kegerejaan, 20\% etika, dan $20 \%$ nilai dan norma; untuk materi bidang penyuluhan agama Katolik adalah $35 \%$ keimanan, $28 \%$ kegerejaan, $17 \%$ etika, dan $20 \%$ nilai dan norma. untuk materi bidang penyuluhan agama Hindu adalah 30\% Sradda, $30 \%$ Susila, $20 \%$ Yadnya, dan 30\% hari-hari suci; dan untuk materi bidang penyuluhan agama Budha adaah semua materi yang diajarkan mempunyai posisi yang sama yaitu $25 \%$.

\section{Hambatan dan Peluang Pelaksanaan Aktivitas pendidikan dalam Penyuluhan Agama}

Hambatan aktifivitas pendidikan dalam penyuluhan agama adalah alat transportasi, tunjangan dan kesungguhan masyarakat, terbatasnya bahan bacaan, sarana dan prasarana, serta pemilihan metode yang sesuai dengan sasaran.

Diagram 1.

Hambatan Penyuluhan

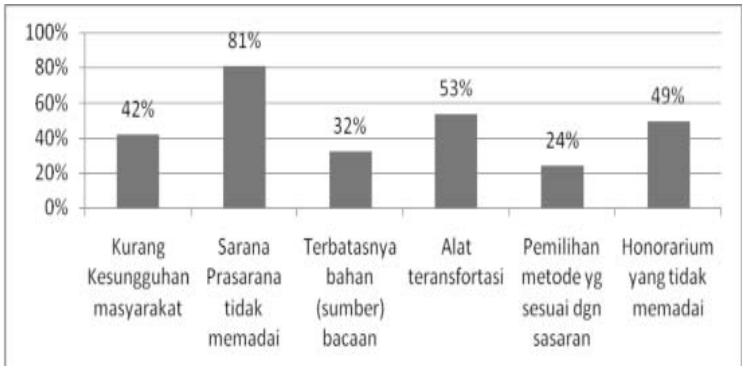

Dari diagram 1 dapat dilihat bahwa sarana dan prasarana yang tidak memadai menjadi faktor pertama aktivitas pendidikan dalam penyuluhan agama. Selain itu ada faktor alat transportasi dan honorarium yang tidak memadai.

Meskipun di satu sisi terdapat faktor penghambat, aktivitas pendidikan penyuluh agama dalam penyuluhan agama juga memilikin peluang yang tinggi. Penyuluh agama memiliki rasa tanggung jawab,kondisi masyarakat kelas bawah yang masih membutuhkan, dan adanya dukungan tokoh masyarakat dalam pelaksanaan penyuluhan. Selain itu, peluang yang dimiliki penyuluh agama adalah keberadaan kelompok kerja penyuluh. Kelompok kerja ini berfungsi antara lain: wadah penyampaian wacana dan ide kerja penyuluhan, wadah bertukar informasi, membantu anggota dalam pemecahan masalah, meningkatkan kinerja penyuluh, dan membantu anggota dalam mengembangkan wawasan kepenyuluhan. 


\section{PENUTUP}

Penelitian peran pendidikan dalam penyuluhan agama di masyarakat disimpulkan. Pertama, ada dimensi atau unsur pendidikan dalam kegiatan penyuluhan agama bahkan penyuluh agama menyamakan antara penyuluhan dengan pendidikan. Dimensi atau unsur pendidikan tercantum dalam KMA No.516 tahun 2003. Kedua, meskipun masih dominan aktivitas yang dikategorikan kepenyuluhan, ada aktivitas kependidikan dalam penyuluhan agama. Ketiga, hambatan dari pada pelaksanaan kegiatan penyuluhan adalah kurangnya sarana dan prasarana, sehingga rasa tanggung jawab sebagai penyuluh agama kurang maksimal serta upaya untuk mengembangkan kemampuan menjadi kurang bersemangat.

Dari kesimpulan tersebut, direkomendasikan kepada unit terkait sebagai penangungjawab penyuluh, untuk memperhatikan hal-hal sebagai berikut: pertama, perlu adanya regulasi yang jelas dan kuat sebagai acuan bagi penyuluh agama dalam pelaksanaan tugas penyuluhan serta penetapan jabatan dan alih fungsi penyuluh. Kedua, sosialisasi terhadap regulasi dan sejenisnya diharapkan menyentuh pada penyuluh di wilayah terpencil, sehingga mereka tahu akan hak dan kewajiban sebagai penyuluh. Ketiga, perlu melakukan veifikasi ulang terhadap penyuluh, mengingat penyuluh ada yang memiliki latar belakang yang tidak sesuai dengan peraturan yang ada. Keempat, perlu disusun sebuah buku pedoman atau standar penyuluhan bagi para penyuluh sebagai acuan dalam melaksanakan tugas penyuluhan di masyarakat. Kelima, perlu dilakukan penataan kembali job discription untuk semua jenjang atau tingkatan, agar tidak terjadi penumpukan pada salah satu kelompok sasaran dan binaan serta penyesuaian dengan ratio jumlah penduduk terhadap keberadaan penyuluh. Keenam, perlu ditinjau kembali tentang penilai jabatan fungsional bagi penyuluh, yang selama ini dirasa kurang tepat keberadaannya. Ketujuh, perlu diberikan sarana dan prasarana bagi kegiatan penyuluhan, untuk memaksimalkan pelaksanaan tugas dan pengembangan SDM bagi penyuluh, dan kedelapan, unit teknis senantiasa memberikan pembinaan terhadap penyuluh sehingga para penyuluh senantiasa dapat selalu mengembangkan dirinya sehingga menjadi penyuluh yang profesional.

\section{SUMBER BACAAN}

Arifin, Muzayyin, Prof., M.Ed. (2010): Filsafat Pendidikan Islam, PT Bumi Aksara, Jakarta.

Al-Syaibani, Omar Mohammad Al-Toumy (1979): Falsafah Pendidikan Islam, Bulan Bintang, Jakarta

Azra, Azumardi (1999): Pendidikan Islam Tradisi dan Modernisasi Menuju Milenium Baru, Logos Wacana Ilmu, cet.1, Jakarta - (2003): Buku Panduan Pelaksanaan Tugas Penyuluhan Agama, Jakarta.

Darajat, Zakiah (2009): Ilmu Pendidikan Islam, Bumi Aksara, Jakarta

Departemen Agama RI (2007): Tehnik Evaluasi dan Pelaporan Penyuluhan Agama Islam

Departemen Agama RI (1996/1997): Operasional Penyuluh Agama

Departemen Agama RI (2000): Himpunan Peraturan Tentang Jabatan Fungsional Penyuluh Agama Dan Angka Kreditnya

Everett, M. Rogers (1995): Diffusion of Inovation, The Free Press, New York

Ihsan, Hamdani, Drs, dan Ihsan, Fuad Ahmad, Drs. (2007): Filsafat Pendidikan Islam, CV Pustaka Setia, Bandung

Jalaluddin. Prof. Dr. H, (2010): Psikologi Agama (Cet. ke-14). Jakarta: PT. Raja Grafindo Persada

Nanang Nizar, Samsul (2002): Filsafat pendidikan Islam, Pendekatan Historis dan Praktis, Cet.1 Ciputat Pers, Jakarta

(2004): Panduan Tugas Operasional Penyuluhan Agama Islam, Jakarta

Ravik Karsidi (2005); Sosiologi Pendidikan, UNS Press, Surakarta 
Ramayulis. Prof. Dr. H. (2003): Psikologi Agama. Jakarta: Kalam Mulia

Shaleh, Abdul, Rahman (2005): Pendidikan Agama dan Pembangunan Untuk Bangsa.Jakarta: PT. Raja Grafindo Persada.

Saleh, Abdul Rahman. (1999): Pendidikan Agama dan Keagamaan, Visi, Misi, dan Aksi, Jakarta : PT Maries

Sahertian, Piet A. (2000): Konsep-Konsep dan Teknik Supervisi Pendidikan Dalam Rangka Pengembangan Sumber Daya Manusia. Jakarta: Rineka Cipta.

Tafsir, Ahmad (2005): Ilmu Pendidikan Dalam Persfektif Islam, Bandung: PT. Remaja Rosdakarya

Tirtarahardja, Umar dan S.L.La Sulo (2005): Pengantar Pendidikan, Rineka Cipta, Jakarta

UU Sisdiknas No. 20 Tahun 2003 pasal 8 tentang hak masyarakat.

WAMI Lembaga Penelitian dan Penelitian (1995): Gerakan Keagamaan dan Pemikiran, terjemahan bahasa Indonesia, Penerbit AlIshlahi Press, Jakarta

Zuhairini, dkk. (1992): Sejarah Pendidikan Islam, Bumi Aksara, Cet.3, Jakarta

Zuhairini, (1983): Metodik Khusus Pendidikan Agama. Surabaya: Usaha Nasional. 